Yüzüncü Yil Üniversitesi
Tarim Bilimleri Dergisi

Araştırma Makalesi (Research Article)

\title{
Akdeniz Bölgesinde Çeltik Yanıklık Hastalığı (Pyricularia oryzae)'nın Yönetiminde Farklı İlaçlama ve Ekim Yöntemlerinin Etkinliğinin Belirlenmesi***
}

\author{
Efkan AKÇALI" ${ }^{* 1}$, Şener KURT ${ }^{2}$ \\ ${ }^{1}$ Tarım ve Orman Bakanlığı, Biyolojik Mücadele Araştırma Enstitüsü, 01321, Adana, Türkiye \\ ${ }^{2}$ Hatay Mustafa Kemal Üniversitesi, Ziraat Fakültesi, Bitki Koruma Bölümü, 31060, Hatay, Türkiye \\ ${ }^{1}$ https://orcid.org/0000-0002-5486-7502 ${ }^{2}$ https://orcid.org/0000-0003-4545-5968 \\ *Sorumlu yazar e-posta: akcaliefkan@hotmail.com; efkan.akcali@tarimorman.gov.tr
}

\section{Makale Bilgileri}

Geliş: 15.04 .2020

Kabul: 28.05.2021

Online Yayınlanma 30.06.2021

DOI: 10.29133 /yyutbd.844852

Anahtar kelimeler

Çeltik,

Çeltik yanıklık hastalı̆̆ı,

Hastalık yönetimi.
Öz: Çeltik, insan beslenmesinde önemli besin kaynaklarından birisidir. Çeltik yanıklık hastalığına neden olan Pyricularia oryzae çeltik yetiştirilen alanlarda görülen en yıkıcı hastalıktır. Bu çalışmanın amacı Akdeniz Bölgesinde çeltik alanlarında yanıklık hastalığına karşı farklı ilaçlama ve ekim şeklinin hastalık şiddeti ve verim üzerine etkisinin araştırılmasıdır. Tarla denemeleri, 2011 ve 2012 yıllarında sırasıyla Adana İli Yüreğir ilçesi, Tabaklar Köyü’nde ve Mersin ili Silifke ilçesi Sökün Köyü'nde Edirne çeşidi yetiştirilen çeltik tarlasında yapılmıştır. Bu çalışma sonucunda, ilaçlı tohum ekimi ve fide dikimi hastalık şiddetini düşürmüştür. En düşük hastalık şiddetinin yıllara göre \% 6.1 ve \%9.3 ile ilaçlı tohum şeklinde fide dikimi yapılan parselde olduğu belirlenmiştir. İlaçlı tohum şeklinde fide dikimi yapılan parselde yeşil aksam ilaçlaması sonucunda da hastalık şiddeti yıllara göre \% 6.6 ve \% 4.6 ile en düşük bulunmuştur. Farklı ilaçlama metodu ve ekim yöntemlerinin ise verim üzerine etkisi gözlenmemiştir.

\section{Determination of the Efficacy of Different Spraying and Planting Methods on Management of Rice Blast Disease (Pyricularia oryzae) in the Mediterranean Region}

\section{Article Info}

Received: 15.04 .2020

Accepted: 28.05.2021

Online Published 30.06.2021

DOI: $10.29133 /$ yyutbd.844852

\section{Keywords}

Rice,

Rice blast disease,

Disease management.

\begin{abstract}
Rice is one of the important food sources in human nutrition. Rice blast disease caused Pyricularia oryzae is the most destructive disease which is seen in rice growing. The aim of this study was to investigate the effect of different spraying and planting methods on disease severity and yield in rice fields in the Mediterranean Region. Field trials were conducted onto rice fields which were grown Edirne variety in the Tabaklar village, Yüregir, Adana province and Sökün village, Silifke, Mersin province in 2011 and 2012, respectively. As a result of this study, the use of treated seeds and seedlings reduced the severity of the disease. The lowest disease severity was found as $6.1 \%$ and $9.3 \%$ where it was used by years. However, the disease severity was also recorded as the lowest value by $6.6 \%$ and $4.6 \%$, respectively through foliar spraying in the plot where the seedlings were performed from treated seeds by years. No impact on different spraying and planting methods on the yield was found.
\end{abstract}




\section{Giriş}

Dünyada stratejik önemi yüksek bitki türlerinden birisi olan çeltik (Oryza sativa L.), insan beslenmesinde buğday bitkisinden sonra gelen önemli gıda maddelerinden biridir. Diğer bir deyişle çeltik, dünya nüfusunun \% 50'sinden fazlası için önemli bir temel gıda ürünüdür ve özellikle Asya gıda pazarlarına hakimdir.

Beslenmeleri nişasta esasına dayalı ve özellikle iklim koşullarının çeltik tarımını zorunlu kıldığı ülkelerde, çeltik yetiştiriciliğinin önemi çok daha fazla ön plana çıkmaktadır.

Dünyada yaklaşık 166 milyon hektar alanda 770 milyon ton çeltik üretimi yapılmaktadır. Dünya çeltik üretim miktarının yaklaşık \% 90.3 Asya kıtasında gerçekleşmektedir. Dünya üretiminde Çin, 208 milyon ton ile \% 27'lik paya sahip iken bu ülkeyi \% 22 ile Hindistan ve \% 9.7 ile Endonezya takip etmektedir (Anonim, 2018a). Türkiye'de Marmara, Karadeniz, Güneydoğu Anadolu, Akdeniz ve Ege bölgelerinde 120 bin hektar alanda 940 bin ton çeltik üretilmektedir. Toplam çeltik üretiminin \% 94'lük kısmı, Marmara ve Karadeniz bölgelerinde gerçekleştirilmektedir (Anonim, 2018b).

Dünyada ve ülkemizde çeltik ekimi, çoğunlukla tohumların su dolu tavalara serpme yöntemi ile yapılmaktadır. Ayrıca, üretim esnasında kullanılan suyun \% 35 oranında azaltılabilmesi ve yabanc1 otlarla daha iyi mücadele edilebilmesi (De Datta, 1981) amacıyla fide yastıklarında yetiştirilen fidelerin, fideleme makinası vasıtasıyla tarlada oluşturulan tavalar içine şaşırtılması suretiyle yetiştiricilik yapilmaktadır.

Çelik üretiminin \% 37'sinin hastalık ve zararlı nedeniyle kaybedilmektedir. Fungusların neden olduğu çeltik hastalıkları, pirinç üretiminde ana kısıtlayıcı faktör olarak kabul edilir ve hem kalitatif hem de kantitatif kayıplara neden olur (Kongcharoen ve ark., 2020). Özellikle çeltikte Pyricularia oryzae'nin neden olduğu yanıklık, yol açtığı \% 50'ye varan verim kayıplarından dolayı en önemli hastalık olarak bildirilmiştir (Nalley ve ark., 2016). Bu fungus, fide aşamasından başlayarak tüm büyüme aşamalarında pirinci enfekte ederek, pirinç yapraklarına ciddi zarar verebilmektedir. Duyarlı çeltik çeşitlerinde uygun koşullarda $\left(25-30^{\circ} \mathrm{C}\right.$ sicaklık ve \% 80-95 nem) \% 80'e varan kayıplara neden olabilir. Çeltik ekim alanlarında Pyricularia oryzae Cavara (syn. Magnaporthe oryzae B. C. Couch)' nın neden olduğu çeltik yanıklık hastalığı, her yıl görülebilen ve zaman zaman büyük epidemilere neden olan hastalıkların başında gelmektedir. Bu patojeni çeltik kök çürüklüğü (Gibberella fujikuroi (Saw.) Wr., Fusarium moniliforme Sheld.) ve çeltik kahverengi yaprak lekesi (Cochliobolus miyabeanus (Ito and Kuribayashi) Drechslerex Dastur Drechslera oryzae (Breda de Haan) Subram \& Jain) takip etmektedir (Aktaş ve Tunal1, 1986).

Çeltik yanıklık hastalığı etmeni Magnaporthe grisea [anamorph Pyricularia grisea (Cooke) Sacc., syn. Pyricularia.oryzae Cav.], Ascomycota şubesi Sordariomycetes sinıfindan Magnaporthales takımına bağlı Magnaporthaceae familyası içerisinde yer alan heterotallik bir fungustur. P.oryzae etmeninden kaynaklanan hastalığın oluşum ve şiddetindeki değiş̧iklikler; yıl, bölge, çeşit, ürün yönetim uygulamaları ve çevre şartlarına bağlı olarak farklılık göstermektedir (Ou, 1985). Mücadele yapılmadığı taktirde duyarlı çeşitlerin yetiştirildiği alanlarda \% 60-100 arasında değişen oranlarda verim kaybına neden olabilmektedir (Aravindan ve ark., 2016). Ülkemizde çeltik yanıklık hastalığının, Karadeniz Bölgesi'nde Tortum vadisinde \% 75'lere varan düzeyde, Sinop, Ünye ve Terme' de \% 25-75 arasında, İç Anadolu Bölgesi'nde ise oransal nemin düşük olması nedeniyle \% 7'yi geçmeyen seviyede ürün kayıplarına neden olduğu bildirilmiştir (Anonim, 1995). Fungus, çeltik bitkisinin toprak üstü tüm aksamlarında enfeksiyon oluşturmakta olup bir yıldan diğer bir yıla çeltik anızları, yabancı otlar ve tohumla geçebilmekte ve bu geçiş yollarının en önemlisinin tohumla olduğu bilinmektedir.

Çeltik yanıklık hastalığı, küresel gıda güvenliğini tehdit eden ciddi bir fungal hastalıktır. Gelecekteki araştırmalar için tüm bitki koruma uygulamaları, entegre bir yaklaşımın parçası olmalı ve gelecekteki iklim koşullarında çeltik yanıklık hastalığının kontrolü için adaptasyon ve azaltma stratejileri geliştirmeye odaklanmalıdır (Asibi ve ark., 2019). Ülkemizde ve dünyada çeltik yanıklık hastalı̆̆ının mücadelesinde yaygın olarak kimyasal mücadele yöntemi uygulanmaktadır. Bu amaçla; hastalığa karşı yeşil aksam ilaçlaması için, azoxystrobin + flutriafol, azoxystrobin + epoxiconazole, pyraclostrobin, picoxystrobin + cyproconazole, tebuconazole + azoxystrobin, trifloxystrobin + tebuconazole, trifloxystrobin, azoxystrobin, azoxystrobin + propiconazole, prochloraz + propiconazole, prochloraz+ epoxiconazole, propiconazole + azoxystrobin + cyproconazole,, boscalid + kresoximmethylgibietken maddeli fungisitlerin yanısıra fluxapyroxad etken maddeli fungisitler tohum ilacı 
olarak ruhsatlı bulunmaktadır (Anonim, 2020). Bazı ülkelerde; tohum fungisiti olarak melanin biyosentezini engelleyerek bitkinin direncini uyaran pyroquilon ve probenazole etken maddeli fungusitler kullanılmaktadır. Bununla mücadele etmek için en etkili, ekonomik olarak uygulanabilir ve çevre dostu strateji, dayanıklı çeşitlerin geliştirilmesidir.

Sürdürülebilir tarımda, çevre sorunları ve pirinç yetiştiriciliğinde önemli ilerleme kaydetmek için çeltik yanıklık hastalığının biyolojik kontrol çözümüne ihtiyaç vardır (Chen ve ark., 2019). Yapılan çalışmada elde edilen mikroorganizmaların antifungal aktivitesi (B. subtilis, B. cereus ve $P$. fluorecens), çeltik patojeninin (M. oryzae) büyümesini engelleme yeteneklerini göstermiştir. Çeltik yanıklık hastalığı ile biyolojik mücadele kapsamında yapılan bir çalışmada (Gohel ve Chauhan, 2015), Trichoderma spp. ile yaprak uygulamasının etkili olduğunu kanıtlayarak çeltik yanıklık hastalığının oluşum düzeyini azalttığ 1 ve verim parametrelerini arttırdığını bildirmiştir.

Dünyada olduğu gibi ülkemizde de hastalıkla mücadelede uçakla yeşil aksam ilaçlanmasının yapılmaması, tohum fungusiti olarak ruhsatl bir bitki koruma ürününün bulunmaması, P.oryzae ile çeltik bitkisi arasındaki interaksiyonun, gen için gen ilişkisi ile yönetilmesi, fungusun bitki tarafindan hemen tanınamaması, oluşan uyumlu ilişki ile konukçunun tepkisinin gecikmesi ve geciken bağışıklık tepkisi sonucu üretilen fitoaleksinlere karşı koyabilmek için patojen mekanizmalarının değişikliğe uğraması sonucu bitki dayanıklılığının kısa sürede kırılması, yıllara göre çeltik yanıklık hastalığına yakalanma sıklığı ile hastalığın salgın yapma sürecindeki dalgalanmalar sonucu kullanılan fungisitlerin etki düzeylerindeki azalmalar hastalığın yönetimini güçleştirmektedir.

Bu çalışma, hastalığın şiddetini azaltarak oluşabilecek verim kayıplarını önleyebilmek amacıyla tohum ilaçlaması, ekim şekli ve yeşil aksam ilaçlamasının hastalık şiddeti üzerine etkisi ile farklı ilaçlama metodu ve ekim yöntemlerinin verim üzerine etkisinin tespit edilmesi amaciyla yapılmıştır. $\mathrm{Bu}$ çalışma bu kapsamda bir ilk niteliğindedir.

\section{Materyal ve Yöntem}

Deneme, 2011 yılında Adana ili Karataş ilçesine bağlı Tabaklar Köyü'nde (36 $46^{\prime} 11 \mathrm{~K}, 035^{\circ}$ 03' 37 D koordinatında) ve 2012 yilında Mersin'in Silifke ilçesine bağlı Sökün Köyü’nde (36 $16^{\circ} 57$ $\mathrm{K}, 033^{\circ} 59^{\prime} 15 \mathrm{D}$ koordinatında) hastalığın yaygın olduğu çeltik üretim alanlarında kurulmuştur. Deneme de Edirne çeltik çeşidi, thiophanate-methyl (\% 70) ve trifloxystrobin (\% 50) etken madde içeren bitki koruma ürünleri (BKÜ) kullanılmıştır.

\subsection{Deneme parselinin kurulması}

Deneme; bölünen bölünmüş parseller deneme desenine göre 8 karakter ve 3 tekrarlı olacak şekilde kurulmuştur (Çizelge 1).

Çizelge 1. İki farklı çeltik üretim alanında gerçekleştirilmiş olan denemenin karakterlere göre kurulum planı

\begin{tabular}{cc}
\hline Ekim Şekilleri & Uygulamalar \\
\hline \multirow{2}{*}{ Tohum Ekimi } & İlaçlı Tohum Ekimi \\
& İlaçsı Tohum Ekimi \\
& İlaçlı Tohum + Yeşil Aksam İlaçlaması \\
& Ilaçsı Tohum + Yeşil Aksam İlaçlaması \\
\hline \multirow{2}{*}{ Fide Dikimi } & İlaçlı Fide Dikimi \\
& İlaçsı Fide Dikimi \\
& İlaçlı Fide + Yeşil Aksam İlaçlaması \\
& İlaçsı Fide + Yeşil Aksam İlaçlaması \\
\hline
\end{tabular}

Deneme parsellerinde kullanılmak üzere 2004 yılında tescil edilen ve çeltik yanıklık hastalığına karşı hassas olduğu bilinen Edirne çeşidi, Tarım ve Orman Bakanlığı'na bağlı Trakya Tarımsal Araştırma Enstitüsü Müdürlüğü'nden temin edilmiş̧tir. Tohum ilaçlaması yapılacak tohumlar, daldırma yöntemi ile $200 \mathrm{~g} / 100 \mathrm{~L}$ su dozunda thiophanate-methyl (Çizelge 2) içerisinde 30 saat süre ile bekletilerek ekime hazır hale getirilmiştir. 
Çizelge 2. Denemeye alınan fungisitlere ait bazı özellikler

\begin{tabular}{lccc}
\hline Etkili Madde Adı ve Oranı & Kimyasal Grup & Ticari Ad 1 & Dozu \\
\hline Thiophanate-methyl \% 70 & Benzimidazole & Sumitop & $200 \mathrm{~g} / 100 \mathrm{~L}$ \\
Trifloxystrobin \% 50 & Strobilurinler & Flint & $20 \mathrm{~g} / 100 \mathrm{~L}$ \\
\hline
\end{tabular}

Her iki yılda sözü edilen lokasyonlarda kurulan $9 \mathrm{~m}^{2}$ büyüklüğündeki deneme parsellerine tohumlar, dekara $20 \mathrm{~kg}$ olacak şekilde serpme usulü ile ekilmiştir. Uygulamaların birbirini etkilemelerini önlemek için bloklar arası $1 \mathrm{~m}$ ve parseller arası iki sıra aralık bırakılmıştır.

Fide elde etmek için hazırlanan tohumlar, tarlaya ekim ile aynı tarihte içinde kum, toprak ve organik gübre karışımından (1:1:1) oluşan fide harcı bulunan viyollere ekilerek yaklaşık 12 gün süre ile yetiştirilmiştir. Deneme parsellerine aktarılmaya uygun hale gelen fideler, $9 \mathrm{~m}^{2}$ büyüklügündeki parsellere sıra aras $25 \mathrm{~cm}$ ve sıra üzeri $20 \mathrm{~cm}$ olacak şekilde 12 siralı olarak dikilmiştir. Deneme parsellerine ekim öncesi taban gübresi olarak her parsele 15.15 .15 kompoze gübreden $200 \mathrm{~g}$ ve salkım oluşturma döneminde üre gübresinden her parsele $150 \mathrm{~g}$ olacak şekilde uygulanmıștır.

İlk yıl kurulan denemede; yabanc1 otlardan darıcan (Echinochloacrus-galli) ile mücadelede Cyhalofob-butyl 200g/L ve kizotu (Cyperus difformis), topalak(Cyperus rotundus) ile mücadelede halosulfuron-methyl $3 \mathrm{~g} / \mathrm{da}$, ertesi y1l deneme parselinde darıcan (Echinochloacrus-galli) ve topalak (Cyperus rotundus) ile mücadele amaçlı Cyhalofob-butyl $200 \mathrm{~g} / \mathrm{L}$ ve halosulfuron-methyl 3g/da dozunda herbisit uygulanmıştır.

Yeşil aksam ilaçlaması birinci yıl hastalık belirtisinin çeltik parsellerinde görüldüğü eylül ayı başında, ikinci yıl ağustos ayı sonunda yapılmıştır. Yeşil aksam ilaçlamasında $20 \mathrm{~g} / \mathrm{da}$ hesabı ile kalibrasyonu yapılmış ve sırt pülverizatörü ile trifloxystrobin fungusiti (\% 50 etken madde içeren) uygulanmıştır.

\subsection{Sayım ve değerlendirmeler}

Birinci yıl hastalık belirtisinin çeltik parsellerinde görüldügü eylül ayının ilk haftasında, ikinci yıl ağustos ayının sonunda her parselin sekiz ayrı yerine atılan $1 / 4 \mathrm{~m}^{2}$ lik kare çember içinde kalan bitkilerden rastgele 50 yaprak alınarak 0-9 skalası (Anonim, 1996)'na göre değerlendirilerek hastalık şiddeti belirlenmiştir.

Çeltik yanıklık hastalığının yapraklarda oluşturduğu belirtilerini esas alarak yapılan değerlendirmede kullanılan 0-9 skalası (Anonim, 1996);

0: Enfeksiyon yok, 1: Toplu iğne başı büyüklüğünde küçük kahverengi lezyonlar, 2: Genişlemiş kahverengi lezyonlar, 3: Kahverengi sınırlı, 1-2 mm çapında, küçük, hafif yuvarlak ve uzunca gri nekrotik lekeler, 4: Elips şeklinde 1-2 cm uzunluğunda iki damar arasını kaplamış, yaprak yüzeyinin \% 2'den azını kaplayan tipik yanıklık lekeleri, 5: Yaprak alanının \% 10'una kadar olan kısmını kaplayan tipik yanıklık lekeleri, 6: Yaprak alanının \% 10-25'ini etkileyen tipik yanıklık lekeleri, 7: Yaprak alanının \% 26-50'sini etkileyen tipik yanıklık lekeleri, 8: Yaprak alanının \% 51-75'ini etkileyen tipik yanıklık lekeleri, bazı yapraklar ölmüş, 9: Bütün yapraklar ölmüş.

Birinci ve ikinci y1l hastalık belirtilerinin görüldügü dönemlerde yeşil aksam ilaçlaması yapılmıştır. Yeşil aksam uygulamasından sonra bitkilerden rastgele tekrar 50 yaprak alınarak 0-9 skalasına göre değerlendirilerek, Towsend-Heuberger'e göre hastalık şiddeti (\%) ve Abbott formülü yardımı ile etkileri (\%) belirlenmiştir. Hastalığın tanılaması, patojenin bitkide oluşturduğu belirtiler göz önüne alınarak yapılmıştır. Belirtilerin patojene ait olduğunu doğrulamak için hastalık belirtisi gösteren bitki dokularından ve organlarından laboratuvarda izolasyonlar yapılarak, morfolojik tanıs1 ve patojenisite testleri gerçekleştirilmiştir.

Yeşil aksam ilaçlama sonrası, olgunlaşma döneminde uygulama yapılan ve yapılmayan parsellerin 4 farklı yerine atılan $1 / 4 \mathrm{~m}^{2}$ 'lik çember içinde kalan tüm bitkiler, ilk y1l ekim ayının ikinci haftası, ikinci yıl ise eylül ayının son haftası olacak şekilde bir kez hasat işlemi gerçekleştirilmiştir. Her bir parselin 4 farklı yerine atılan $1 / 4 \mathrm{~m}^{2}$ lik çember içinde kalan tüm bitkilerin salkımları kesilerek ayrı ayrı verimleri hesaplandıktan sonra farklı ilaçlama ve ekim yöntemlerinin, hastalığın kontrolü ve verime olan etkisi Duncan Çoklu Karşılaştırma Testi ile değerlendirilmiştir. 


\section{Bulgular}

\subsection{Tohum ilaçlaması ve ekim şeklinin hastalık şiddeti üzerine etkisi}

Tohum ilaçlaması yapılan ve yapılmayan üretimde fide dikimi ve tohum ekiminin hastalık şiddeti üzerine etkisini belirlemek amaciyla kurulan deneme parsellerinde görülen ortalama hastalık şiddeti belirlenmiştir (Çizelge 3). Elde edilen bulgulara göre, ilk y1l üretim sezonunda en düşük hastalık şiddeti \% 6.1 ile ilaçlı tohumla yapılan üretimde fide dikiminde görülürken, en yüksek hastalık şiddeti $\% 10.8$ ile ilaçsız tohumla yapılan üretimde tohum ekiminde belirlenmiştir.

Çizelge 3. 2011 yılı tohum ilaçlaması ve ekim şeklinin hastalık şiddeti (\%) üzerine etkisi

\begin{tabular}{lccc}
\hline \multicolumn{1}{c}{ Uygulamalar } & Fide Dikimi & Tohum Ekimi & Ortalama \\
\hline İlaçlı Tohumla Yapılan Üretim & 6.1 & 8.7 & $7.4 \mathrm{a}^{*}$ \\
İlaçsız Tohum Yapılan Üretim & 7.3 & 10.8 & $9.1 \mathrm{~b}$ \\
\hline Ortalama & $6.7 \mathrm{a}$ & $9.8 \mathrm{~b}$ & \\
\hline
\end{tabular}

*Sütun içerisinde farklı harflerle gösterilen ortalamalar, Duncan Çoklu Karşılaştırma Testine göre $(\mathrm{P}=0.05)$ birbirinden önemli ölçüde farklıdır

İkinci y1l üretim döneminde ise en düşük hastalık şiddeti \% 9.3 ile ilaçlı tohumla yapılan üretimde fide dikiminde görülürken, en yükssek hastalık şiddeti $\% 17.6$ ile ilaçsız tohumla yapılan üretimde tohum ekiminde tespit edilmiştir (Çizelge 4).

Çizelge 4. 2012 yılı tohum ilaçlaması ve ekim şeklinin hastalık şiddeti (\%) üzerine etkisi

\begin{tabular}{lccc}
\hline \multicolumn{1}{c}{ Uygulamalar } & Fide Dikimi & Tohum Ekimi & Ortalama \\
\hline İlaçlı Tohumla Yapılan Üretim & 9.3 & 13.3 & $11.3 \mathrm{a}^{*}$ \\
İlaçsız Tohum Yapılan Üretim & 12.1 & 17.6 & $14.9 \mathrm{~b}$ \\
\hline Ortalama & $10.7 \mathrm{a}$ & $15.5 \mathrm{~b}$ & \\
\hline
\end{tabular}

*Sütun içerisinde farklı harflerle gösterilen ortalamalar, Duncan Çoklu Karşılaştırma Testine göre $(\mathrm{P}=0.05)$ birbirinden önemli ölçüde farklıdır.

Her iki yılda kurulan deneme parsellerinden elde edilen değerlerin birbirleri ile uyumlu olduğu ve yapılan varyans analizine göre (ANOVA) ekim şeklinin ve tohum ilaçlamasının önemli $(\mathrm{P}=0.05)$ olduğu, her ikisinin interaksiyonunun önemsiz $(\mathrm{P}=0.05)$ olduğu bulunmuştur.

\subsection{Yeşil aksam ilaçlaması ve ekim şeklinin hastalık şiddeti üzerine etkisi}

Yeşil aksam ilaçlaması ve ekim şekillerinin hastalık şiddeti (\%) üzerine etkisini belirlemek amaciyla 2011 ve 2012 yılı üretim döneminde deneme parsellerinde görülen ortalama hastalık şiddeti değerleri belirlenmiştir.

2011 y1lı üretim döneminde en düşük hastalık şiddeti \% 6.6 ile ilaçlı tohumdan üretilen fideler üzerinde yeşil aksam ilaçlama uygulamasında görülürken, en yüksek hastalık şiddeti değeri \% 11.7 ile ilaçlı tohumla üretimi yapılan tohuma yeşil aksam ilaçlama yapılmayan uygulamada belirlenmiştir. 2011 y1lı yetiştiricilik döneminde tohum veya fide dikimi şeklinde yapılan uygulama istatistiksel olarak farklı gruplarda yer almış olup, fide dikiminde \% 7.9 ortalama değeri ile en az hastalık şiddeti elde edilirken, tohum ekimi şeklinde yapılan üretimde \% 10.7 ortalama değeri ile en fazla hastalık şiddeti elde edilmiştir. Yeşil aksam ilaçlaması hastalık oluşumunu azaltmış ve yeşil aksam ilaçlaması yapılan parsellerle, yapılmayan parsellerde istatistiksel olarak hastalık şiddeti farklılık göstermiştir. Yeşil aksam ilaçlaması yapılan parsellerde hastalık şiddeti \% 8.6 olurken, yeşil aksam ilaçlaması yapılmayan parsellerde hastalık şiddeti \% 10 olarak kaydedilmiştir (Çizelge 5). 
Çizelge 5. 2011 yılı yeşil aksam ilaçlaması ve ekim şeklinin hastalık şiddeti (\%) üzerine etkisi

\begin{tabular}{clccc}
\hline Uygulamalar & & Fide Dikimi & Tohum Ekimi & Ortalama \\
\hline $\begin{array}{c}\text { Yeşil Aksam } \\
\text { İlaçlamas1 } \\
(+)\end{array}$ & İlaçlı Tohum & 6.6 & 9.7 & \\
\hline $\begin{array}{c}\text { Yeşil Aksam } \\
\text { İlaçlamas1 } \\
(-)\end{array}$ & İlaçsız Tohum & 8.1 & 9.9 & $8.6 \mathrm{a}^{*}$ \\
\hline İlaçlı Tohum & İlaçsız Tohum & 7.8 & 11.7 & \\
\hline Ortalama & 9.0 & 11.3 & $10.0 \mathrm{~b}$ \\
\hline
\end{tabular}

*Sütun içerisinde farklı harflerle gösterilen ortalamalar, Duncan Çoklu Karşılaştırma Testine göre $(\mathrm{P}=0,05)$ birbirinden önemli ölçüde farklıdır.

2012 y1lı yetiştiricilik döneminde en düşük hastalık şiddeti \% 4.6 ile ilaçlı tohumdan üretilen fideler üzerinde gerçekleştirilen yeşil aksam ilaçlama uygulamasında görülürken, en yükssek hastalık şiddeti \% 17.6 ile ilaçsız tohumla üretimi yapılan bitkilere yeşil aksam ilaçlama yapılmayan uygulamada belirlenmiştir. 2012 y1lı üretim döneminde tohum veya fide dikimi şeklinde yapılan üretim istatistiksel olarak farklı gruplarda yer almış olup, fide dikiminde \% 7.9 ortalama değeri ile en az hastalık şiddeti elde edilirken, tohum ekimi şeklinde yapılan üretimde \% 11.1 ortalama değeri ile en fazla hastalık şiddeti elde edilmiştir. Yeşil aksam ilaçlaması hastalık oluşumunu azaltmış ve yeşil aksam ilaçlaması yapılan parsellerle yapılmayan parsellerde hastalık şiddeti istatistiksel olarak farklılık göstermiştir. Yeşil aksam ilaçlaması yapılan parsellerde hastalık şiddeti \% 5.9 olurken, yeşil aksam ilaçlaması yapılmayan parsellerde hastalık şiddeti \% 13.1 olmuştur (Çizelge 6).

Çizelge 6. 2012 yılı yeşil aksam ilaçlaması ve ekim şeklinin hastalık şiddeti (\%) üzerine etkisi

\begin{tabular}{clccc}
\hline Uygulamalar & & Fide Dikimi & Tohum Ekimi & Ortalama \\
\hline $\begin{array}{c}\text { Yeşil Aksam } \\
\text { İlaçlaması } \\
(+)\end{array}$ & İlaçlı Tohum & 4.6 & 5.9 & \\
\hline $\begin{array}{c}\text { Yeşil Aksam } \\
\text { İlaçlamas1 } \\
(-)\end{array}$ & İlaçsızlı Tohum & 5.5 & 7.4 & $5.9 \mathrm{a}^{*}$ \\
\hline Ȯlaçs1z Tohum & 9.3 & 13.3 & \\
\hline Ortalama & 12.1 & 17.6 & $13.1 \mathrm{~b}$ \\
\hline
\end{tabular}

*Sütun içerisinde farklı harflerle gösterilen ortalamalar, Duncan Çoklu Karşılaştırma Testine göre $(\mathrm{P}=0,05)$ birbirinden önemli ölçüde farklıdır.

\subsection{Farklı ilaçlama metodu ve ekim yöntemlerinin verim üzerine etkisi}

Farklı ilaçlama metodu ve ekim şekillerinin verim üzerine etkisini belirlemek amaciyla 2011 ve 2012 yılı üretim dönemlerinde deneme parsellerinde ortaya çıkan ortalama verim değerleri belirlenmiştir.

2011 yılındaki çalışmadaki deneme parselinde en yüksek verim, fungusit uygulaması yapılan tohumda $803 \mathrm{~g} / \mathrm{m}^{2}$ olarak tespit edilirken en düşük verim fungusit uygulaması yapılmayan tohumda $668.2 \mathrm{~g} / \mathrm{m}^{2}$ olarak belirlenmiştir (Çizelge 7). 
Çizelge 7. 2011 yılı farklı ilaçlama metodu ve ekim yöntemlerinin verim $\left(\mathrm{g} / \mathrm{m}^{2}\right)$ üzerine etkisi

\begin{tabular}{|c|c|c|c|c|}
\hline & & \multicolumn{3}{|c|}{ Verim $\left(\mathrm{g} / \mathrm{m}^{2}\right)$} \\
\hline \multicolumn{2}{|c|}{ Uygulamalar } & Fide Dikimi & Tohum Ekimi & Ortalama \\
\hline \multirow{4}{*}{$\begin{array}{c}\text { Yeşil Aksam } \\
\text { İlaçlaması } \\
(+)\end{array}$} & İlaçlı Tohum & 679.7 & 722.7 & \\
\hline & & & & \\
\hline & İlaçsız Tohum & 698.3 & 678.1 & \\
\hline & & & & $694.7 \mathrm{a}^{*}$ \\
\hline \multirow{4}{*}{$\begin{array}{c}\text { Yeşil Aksam } \\
\text { İlaçlaması } \\
(-)\end{array}$} & İlaçlı Tohum & 726.8 & 803.0 & \\
\hline & & & & \\
\hline & İlaçsız Tohum & 771.3 & 668.2 & \\
\hline & & & & $742.3 \mathrm{a}$ \\
\hline \multicolumn{2}{|l|}{ Ortalama } & $719.0 \mathrm{a}$ & $718.0 \mathrm{a}$ & \\
\hline \multicolumn{5}{|c|}{$\begin{array}{l}\text { * Sütun içerisinde farklı harflerle gösterilen ortalamalar, Duncan Çoklu Karşılaştırma Testine göre }(\mathrm{P}=0,05) \\
\text { birbirinden önemli ölçüde farklıdır. }\end{array}$} \\
\hline \multicolumn{5}{|c|}{$\begin{array}{l}2011 \text { yılı üretim döneminde tohum veya fide dikimi şeklinde yapılan üretim istatistiksel olarak } \\
\text { ynı gruplarda yer almış olup, fide dikiminde } 719 \mathrm{~g} / \mathrm{m}^{2} \text { ortalama verim elde edilirken, tohum ekimi } \\
\text { eklinde yapılan üretimde } 718 \mathrm{~g} / \mathrm{m}^{2} \text { ortalama verim elde edilmiştir. Yeşil aksam ilaçlaması yapılan } \\
\text { arsellerde } 694.7 \mathrm{~g} / \mathrm{m}^{2} \text { verim elde edilirken, yeşil aksam ilaçlaması yapılmayan parsellerde } 742.3 \mathrm{~g} / \mathrm{m}^{2} \\
\text { erim elde edilmiştir } \\
012 \text { y1lında en yüksek verim ilaçlı fide- ilaçlı yeşil aksamda } 374.4 \mathrm{~g} / \mathrm{m}^{2} \text { en düşük verim ilaçsız tohum } \\
\text { kiminde } 259.9 \mathrm{~g} / \mathrm{m}^{2} \text { olarak belirlenmiştir (Çizelge } 8 \text { ). }\end{array}$} \\
\hline \multicolumn{5}{|c|}{ Çizelge 8. 2012 yılı farklı ilaçlama metodu ve ekim yöntemlerinin verim $\left(\mathrm{g} / \mathrm{m}^{2}\right)$ üzerine etkisi } \\
\hline \multirow{2}{*}{\multicolumn{2}{|c|}{ Uygulamalar }} & & Verim $\left(\mathrm{g} / \mathrm{m}^{2}\right)$ & \\
\hline & & Fide Dikimi & Tohum Ekimi & Ortalama \\
\hline \multirow{3}{*}{$\begin{array}{c}\text { Yeşil Aksam } \\
\text { İlaçlaması } \\
(+)\end{array}$} & İlaçlı Tohum & 374.4 & 319.7 & \\
\hline & İlaçs1z Tohum & 310.4 & 284.9 & \\
\hline & & & & $322.4 a^{*}$ \\
\hline \multirow{4}{*}{$\begin{array}{c}\text { Yeşil Aksam } \\
\text { İlaçlaması } \\
(-)\end{array}$} & İlaçlı Tohum & 270.6 & 310.2 & \\
\hline & & & & \\
\hline & İlaçsız Tohum & 305.9 & 259.9 & \\
\hline & & & & $286.7 \mathrm{a}$ \\
\hline Ortalama & & $315.3 a$ & $293.7 \mathrm{a}$ & \\
\hline
\end{tabular}

*Sütun içerisinde farklı harflerle gösterilen ortalamalar, Duncan Çoklu Karşılaştırma Testine göre $(\mathrm{P}=0,05)$ birbirinden önemli ölçüde farklıdır.

2012 yılı üretim döneminde tohum veya fide dikimi şeklinde yapılan üretim istatistiksel olarak aynı gruplarda yer almış olup, fide dikiminde $315.3 \mathrm{~g} / \mathrm{m}^{2}$ ortalama verim elde edilirken, tohum ekimi şeklinde yapılan üretimde $293.7 \mathrm{~g} / \mathrm{m}^{2}$ ortalama verim elde edilmiştir. Yeşil aksam ilaçlaması yapılan parsellerde $322.4 \mathrm{~g} / \mathrm{m}^{2}$ verim düzeyi saptanırken, yeşil aksam ilaçlaması yapılmayan parsellerde 286.7 $\mathrm{g} / \mathrm{m}^{2}$ verim elde edilmiştir (Çizelge 8 ).

2011 ve 2012 y1l verileri birbirlerini destekler nitelikte olmuş ve yapılan varyans analizine göre (ANOVA) ekim şekli, ilaç uygulaması ve her ikisinin interaksiyonunun önemsiz $(\mathrm{P}=0.05)$ olduğu bulunmuştur. 


\section{Tartışma ve Sonuç}

Bu çalışma sonucunda; tohum ilaçlaması, ekim şekli ve yeşil aksam ilaçlamasının hastalık şiddeti üzerine etkili olduğu, verim üzerine etkisinin olmadığ 1 belirlenmiştir. İlaçlı ve ilaçsız tohum ile yapılan üretimde en düşük hastalık şiddeti değerinin, ilaçlı tohumla yapılan üretimde olduğu tespit edilmiştir. Filippi ve Prabhu (1997) Brezilya'da çeltik yanıklık hastalığının kontrolü üzerinde tohuma fungusit uygulaması ve dayanıklı bitkilerin birleşik etkisi üzerine 2 yıl süre ile yaptıkları çalışmada, farklı dayanıklılık seviyesindeki çeltik çeşitlerine $4 \mathrm{~g} / \mathrm{kg}$ tohum olacak şekilde pyroquilon etkili maddeli fungusitin ortalama yaprak yanıklığını 62 güne kadar ve fide devresinden sonra 47 güne kadar bastırdığını belirlemesi çalışmanın sonuçlarını desteklemektedir.

Tohum ilaçlaması yapılarak üretilen fideler ile tohum ilaçlaması yapılmadan üretilen fidelerin $25 \times 20 \mathrm{~cm}$ aralıklarla dikimi sonucu; İlaçlanmış tohumdan elde edilen fidelerde en düşük hastalık şiddeti oluştuğu, bunun yanı sıra tohum ilaçlaması yapılmadan fide dikimi şeklinde yapılacak üretiminde hastalık şiddetini düşürdüğü belirlenmiştir. Tropik kuşaklarda çeltik yanıklık hastalığının gelişimi ile çiğin ilişkisini belirleme amacıyla yapılan boşluk çalışmalarında, 10x10cm, 20x20 cm ve 40x40 cm sıra arası ve sıra üzeri boşluk bırakılan parsellerde en fazla yanıklık lezyonunun $10 \times 10 \mathrm{~cm}$ sıra aralığında en az yanıklık lezyonunun ise $40 \times 40 \mathrm{~cm}$ sıra aralığında olduğu belirlenmiş ve bunun nedeninin $10 \times 10 \mathrm{~cm}$ aralıkla oluşturulan parsellerdeki çiğ süresinin en fazla, $40 \times 40 \mathrm{~cm}$ aralıkta oluşturulan parsellerde ise en kısa oluşundan kaynaklandığı belirtilmiştir (El-Refai, 1977; IRRI, 1976).

Yeşil aksam ilaçlamasında en düşük hastalık şiddetinin; tohumdan üretilen fidelerin dikimi ile yapılan parsellerde olduğu, bu nedenle ilaçlı tohumdan üretilen fideler üzerine yapılacak yeşil aksam ilaçlamasının hastalığın yönetimi açısından çok önemli olduğu belirlenmiştir. Kapoor ve Singh (1982) $P$. oryzae etmeninin spor çimlenmesi ve apresoryum oluşumunu benomyl'in $1.94 \mathrm{ppm}$ konsantrasyonunun etkili bir şekilde engellediği ve ilaçlamadan sonra 24-25 gün süreyle sistemik etkilerinin devam ederek fideleri koruduğunu tespit etmişlerdir. Bu sonuçlar, çalışmada belirlenen sonuçlarla örtüşmektedir.

Çalışma sonucunda; farklı ilaçlama metodu ve ekim şekillerinin verim üzerine etkisinin olmadığı belirlenmiştir. Padmanabhan (1965) çeltik yanıklık hastalığının meydana getirdiği ürün kaybını tahmin etmek amaciyla; epidemi olan ve olmayan alanlarda, aynı verimi veren duyarlı ve dayanıklı çeşitler üzerine fungusit uygulaması yapılan ve yapılmayan deneme parsellerinde yaptığı çalışmada, tam bir karşılaştırmanın mümkün olmadığını, çünkü başka faktörlerinde bulunduğunu fakat \% 1'lik boyun infeksiyonun \% 1.4 oranında ürünü azalttığını belirtmiştir. Aynı zamanda burada, sepme ekim sonucu oluşacak yaprak 1slaklık sürelerindeki artış sonucu hastalık şiddetinde bir artış olmasına karşın, salkım saplarında enfeksiyon oluşmaması sonucu, yaprak enfeksiyonlarından kaynaklanacak verim kaybının serpme ekimle elde edilebilecek ilave ürün ile dengelendiği, bundan dolayı farklı ilaçlama metodu ve ekim şekillerinin verim üzerine bir etkisinin olmadığı kanaatine varılmıştır. Sezer ve ark. (2017) tane verimi yönünden ekim yöntemleri, çeşitler ve "Ekim yöntemi x Çeşit" interaksiyonu arasındaki farkın çok önemli $(\mathrm{p}<0.01)$ olduğunu belirtmişler ve serpme ekim yönteminde tane verimini $791.22 \mathrm{~kg} / \mathrm{da}$, fideleme ekim yönteminde ise $721.58 \mathrm{~kg} / \mathrm{da}$ olarak belirlemişlerdir.

Sonuç olarak; çeltik yetiştirilen alanlarda üretimi kısıtlayan en önemli hastalıklardan biri olan çeltik yanıklık hastalığının yönetiminde ve şiddetini düşürmede tohum ilaçlamasının, fide dikiminin ve yeşil aksam ilaçlamasının önemli olduğu belirlenmiştir. İlaçlanmış tohumdan elde edilen fideler üzerine yapılacak yeşil aksam uygulamalarının hastalığın şiddetini düşürmede en etkin yöntem olduğu, bunun yanı sıra tohum ilaçlaması yapılmadan fide dikimi şeklinde yapılacak üretiminde ilaçsız tohum ekimine göre hastalık şiddetini düşürdüğü belirlenmiştir.

\section{Kaynakça}

Aktaş, H., \& Tunalı, B. (1986). Türkiye'de ekimi yapılan ümitvar çeltik çeşitlerinin Pyricularia oryzae Bri. et. Cav., Drechslera oryzae Subram. ve Fusarium moniliforme Sheld.'ye karş1 reaksiyonlarının saptanmas1. Bitki Koruma Bülteni, 26(1-2), 41-58.

Anonim. (1995). VII. Türkiye Fitopatoloji Kongresi, 26-29 Eylül 1995 Adana, 16-20.

Anonim. (1996). Tarım ve Köyişleri Bakanlığı Zirai Mücadele Standart İlaç Deneme Metotları. CiltII:18-21. 
Anonim. (2018a). FAO Rice Market Monitor (RMM), Volume XXI, Issue No. 11/38. http://www.fao.org/3/I9243EN/19243en.pdf (Erişim tarihi: 09.03.2020).

Anonim. (2018b). TUIK. http://www.tuik.gov.tr (Erişim tarihi: 09.03.2020)

Anonim. (2020). Tarım ve orman bakanlığı bitki koruma ürünleri veritabanı. https://bku.tarimorman.gov.tr/Arama/Index (Erişim tarihi: 20.12.2020).

Aravindan, S., Yadav, M.K., \& Sharma, P. (2016). Biological control of rice blast disease with Trichoderma spp. under upland rice system. Int J Ric. 53(2), 167-173.

Asibi, A.E., Qiang Chai, Q.C., \& Coulter, J.A. (2019). Rice Blast: A Disease with Implications for Global Food Security. Agronomy, 9, 451.

Chen, W.C., Chiou, T.Y., Delgado, A.L., \& Liao, C.S. (2019). The Control of Rice Blast Disease by the Novel Biofungicide Formulations. Sustainability 11, 3449.

De Datta, S.K. (1981). Principles and Practise of Rice Production. The İnternational Rice Research Institute. Los Banos, The Philippines

El-Refai, M.I. (1977). Epidemiology of rice blast disease in the tropic with special reference to the leaf wetness in relation to disesae development. Ph.D. thesis, Indian Agricultural Research Institute, New Delhi.

Filippi, M.C., \& Prabhu, A.S. (1997). Integrated effect of host plant resistance and fungucidial seed treatment on rice blast control in Brazil. American Phytopathological Society Plant Disease, 81, 351-355.

Gohel, H.L., \& Chauhan, H.L. (2015). Integrated management of leaf and neck blast disease of rice caused by Pyricularia oryzae. Afr. J. Agric. Res. 10, 2038-2040.

IRRI. (1976). Annual Reports for 1964-79.

Kapoor, A.S., \& Singh, B.M. (1982). Evaluation of some fungucides fort he control of rice blast. Indian Phytopathol., 35(4), 558-561.

Kongcharoen, N., Nipon Kaewsalong, N., \& Dethoup, T. (2020). Efficacy of fungicides in controlling rice blast and dirty panicle diseases in Thailand. Scientific Reports 10, 16233.

Nalley, L., Tsiboe, F., Durand-Morat, A., Shew, A., \& Thoma, G. (2016). Economic and environmental impact of rice blast pathogen (Magnaporthe oryzae) alleviation in the United States. PLoS ONE 11, e0167295.

Ou, S.H. (1985). Rice Diseases. 2nd Ed. CAB International Mycological Institute, UK.

Padmanabhan, S.Y. (1965). Estimating losses from rice blast in İndia. The Rice Blast Disease, 203-221. Baltimore,Maryland; Johns Hopkins Press.

Sezer, İ., Şenocak, H.S., \& Akay, H. (2017). Bazı Çeltik Çeşitlerinde Fideleme ve Serpme Ekim Yöntemlerinin Karşılaştırılması. KSÜ Doğa Bil. Derg., 20 (Özel Sayı), 292-296. 